\title{
Effects of enteropathogenic Escherichia coli on microvillar membrane proteins during organ culture of rabbit intestinal mucosa
}

\author{
H Embaye, C A Hart, B Getty, J N Fletcher, J R Saunders, R M Batt
}

\begin{abstract}
This study examines the effects of an enteropathogenic Escherichia coli on microvillar membrane proteins during organ culture of rabbit ileal explants. Explants maintained with enteropathogenic $\boldsymbol{E}$ coli showed brush border effacement affecting approximately $50 \%$ of enterocytes, and where enteropathogenic $E$ coli were closely adherent to the enterocyte surface microvilli were apparently being shed as vesicles. The microvillar membrane enzymes alkaline phosphatase, aminopeptidase $\mathbf{N}$ and $\alpha$-glucosidase were released into the culture medium during organ culture, and this process was significantly enhanced by enteropathogenic $E$ coli. This increased loss of microvillar membrane enzymes into the culture medium was associated with decreased tissue activities of microvillar membrane enzymes in enteropathogenic $E$ coli infected ileal explants compared with control. For aminopeptidase $\mathbf{N}$ in particular, however, total enzyme activities in the tissue plus culture medium were increased comparing enteropathogenic $E$ coli with control, suggesting that there might be an increase in the rate of synthesis of certain microvillar membrane proteins. Reorientating sucrose density gradient centrifugation of culture medium showed that alkaline phosphatase, aminopeptidase $\mathbf{N}$ and $\alpha$-glucosidase were predominantly associated with particles of peak modal density $1.19 \mathrm{~g} / \mathrm{ml}$ in both groups, confirming that enteropathogenic $E$ coli accelerate release of microvillar membrane enzymes as vesicles. Analytical fractionation of ileal explants showed that enteropathogenic $E$ coli resulted in a loss of microvillar membrane enzyme activities from the main brush border peak of modal density $1.21 \mathrm{~g} / \mathrm{ml}$ present in controls. The density of the remaining smaller and lighter peak increased from $1.19 \mathrm{~g} / \mathrm{ml}$ to $1.23 \mathrm{~g} / \mathrm{ml}$ after homogenisation in digitonin, confirming association of these proteins with cholesterol containing membranes and not endoplasmic reticulum. These findings suggest that enteropathogenic $E$ coli accelerate the normal shedding of microvillar membrane proteins as vesicles, and may stimulate a compensatory increase in microvillar membrane protein synthesis.
\end{abstract}

(Gut 1992; 33: 1184-1189)

The strains of Escherichia coli that produce diarrhoea do so by one of at least five distinct mechanisms.' Enteropathogenic $E$ coli were originally delineated as those strains that were neither enterotoxigenic nor enteroinvasive, but it is now known that enteropathogenic $E$ coli produce distinctive ultrastructural damage to the brush border that can seriously interfere with enterocyte function. ${ }^{2}$ This has been described as an attaching effacing lesion which is characterised by close apposition of bacteria to the enterocyte surface associated with a considerable loss of microvilli with cup and pedestal formation at the sites of bacterial attachment. Such damage has been shown to occur during natural and experimentally induced infection of man, ${ }^{3-5}$ rabbits, pigs, ${ }^{7}$ calves, ${ }^{89}$ and cats. ${ }^{9}$

Examination of duodenal mucosa from a child with enteropathogenic $E$ coli 0111 showed that attaching effacement was accompanied by a selective loss of microvillar membrane enzymes, ${ }^{10}$ and comparable changes were observed when the same enteropathogenic $E$ coli 0111 was used to infect rabbit ileal explants in organ culture. "12 The latter technique has facilitated sequential electron microscopic studies which have provided some evidence that microvilli are lost by a process of vesiculation. ${ }^{11-1+}$ These findings have now been pursued by examining the effects of enteropathogenic $E$ coli on microvillar membrane proteins during organ culture of rabbit ileal explants in order to explore the mechanism of damage and response of enterocytes to the loss of microvillar membrane proteins.

\section{Methods}

BACTERIA

The strain of enteropathogenic $E$ coli (K798) used in these experiments was isolated from a child with gastroenteritis, ${ }^{10}$ and had been stored at $-70^{\circ} \mathrm{C}$ in glycerol broth. This enteropathogenic $E$ coli of serogroup $0111 \mathrm{a}, \mathrm{b}, \mathrm{H}^{-}$, did not produce heat labile (LT), heat stable (ST), or vero-cytotoxin (VT), but did exhibit localised adhesion to HEp- 2 cells. It did not contain DNA sequences homologous to the LT, STa, STb, VT1, VT2, and enterohaemorrhagic $E$ coli probes, but did hybridise with the enteropathogenic $E$ coli adherence factor probe ${ }^{15}$ and the $E$ coli attaching effacing (eae) probe. ${ }^{16}$ The enteropathogenic $E$ coli was cultured in brain heart infusion broth (Oxoid Ltd, Basingstoke, $\mathrm{UK}$ ) at $37^{\circ} \mathrm{C}$ for 18 hours. The culture was then centrifuged and the bacteria washed in sterile saline. The enteropathogenic $E$ coli were resuspended to give a final concentration of $10^{8}$ $\mathrm{cfu} / \mathrm{ml}$ in organ culture medium consisting by volume of $65 \%$ Trowells T8 culture medium, $20 \%$ NCTC 135 and $15 \%$ fetal calf serum (Gibco, 
Figure 1: Electron microscopic appearance of rabbit ileal explant maintained with enteropathogenic E coli for eight hours showing vesiculation $(V)$ of microvill in areas where bacteria are closely adherent to the enterocyte surface, and some microvilli $(M)$ cut in section in adjacent areas with $a$ normal brush border. Bar represents $1 \mu \mathrm{m}$.

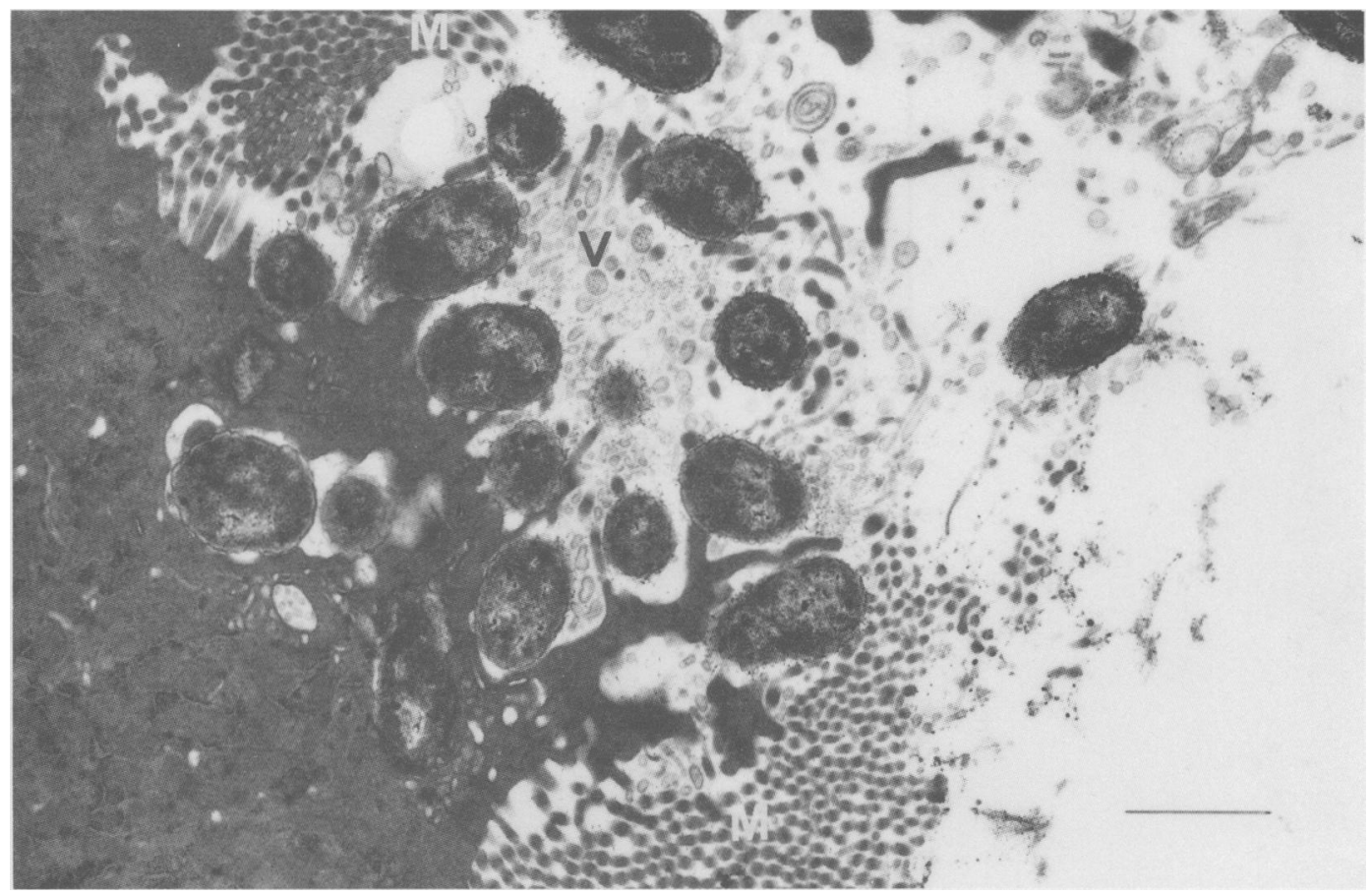

Paisley, UK) containing benzyl penicillin (60 $\mathrm{mg} / \mathrm{l})$ and L-glutamine ( $2 \mathrm{mmol} / \mathrm{l})$.

\section{ORGAN CULTURE}

Ileal mucosal fragments obtained from adult Dutch rabbits (average weight $2.5 \mathrm{~kg}$ ) were maintained in organ culture as described previously. " The rabbits were fasted overnight and anaesthetised with Valium (Roche Ltd, Welwyn, UK) and Hypnorm (Crown Chemical Co, Ltd, Lamberhurst, UK). The ileum was exteriorised through a vertical midline incision and the mucosa was flushed with prewarmed $\left(37^{\circ} \mathrm{C}\right)$ iso-osmotic saline. Mucosal fragments were taken randomly from a $5 \mathrm{~cm}$ region extending from $5 \mathrm{~cm}$ to $10 \mathrm{~cm}$ proximal to the ileocaecal valve using iridectomy scissors. Each fragment was washed in pregassed $\left(95 \% \mathrm{O}_{2}: 5 \% \mathrm{CO}_{2}\right)$ prewarmed $\left(37^{\circ} \mathrm{C}\right)$ organ culture medium and trimmed into small fragments (approximately $2 \mathrm{~mm}^{3}$ ). The fragments were suspended for 10 min either in organ culture medium containing enteropathogenic $E$ coli $\left(10^{8} \mathrm{cfu} / \mathrm{ml}\right)$ or in organ culture medium alone (control). Then the fragments were removed, separated and incubated for 24 hours at $37^{\circ} \mathrm{C}$ in an atmosphere of $95 \% \mathrm{O}_{2}$ and $5 \% \mathrm{CO}_{2}$ on stainless steel grids in contact with organ culture medium in sterile dishes.

\section{ULTRASTRUCTURAL STUDIES}

The ileal fragments were fixed for one hour in cacodylate buffered glutaraldehyde $(2 \cdot 5 \% \mathrm{v} / \mathrm{v})$, washed three times in cacodylate buffer and refixed with osmium tetroxide $(1 \% \mathrm{v} / \mathrm{v})$. They were then washed three times in distilled water, embedded in araldite, thin sectioned and stained with Reynold's lead citrate and uranyl acetate $(1 \% \mathrm{v} / \mathrm{v})$. Thin sections were mounted on 200 mesh copper grids and examined using a Philips 301 electron microscope.
BIOCHEMICAL STUDIES

In each experiment, explants and culture medium from pairs of organ culture dishes, each pair containing three control or enteropathogenic $E$ coli infected mucosal fragments, were pooled separately. Pooled explants were homogenised in $5 \mathrm{ml}$ sucrose medium $(0.3 \mathrm{mmol} / 1$ sucrose, $22 \mathrm{mmol} / \mathrm{l}$ ethanol, $1 \mathrm{mmol} \mathrm{Na}$ EDTA, $\mathrm{pH} 7 \cdot 4)$ with or without digitonin $(0.12 \mathrm{mmol} / \mathrm{l})$, and a postnuclear supernatant was prepared by low speed centrifugation $(800 \mathrm{~g})$ in a refrigerated centrifuge (Sorvall RT 6000). ${ }^{17}$ The nuclear pellet was further homogenised in $2 \mathrm{ml}$ sucrose medium and stored at $-20^{\circ} \mathrm{C}$ for enzyme assays. An aliquot $(3 \mathrm{ml})$ of each postnuclear supernatant or pooled organ culture medium (diluted $1: 1$ in sucrose medium) was subjected to reorientating sucrose density gradient centrifugation by layering onto a sucrose gradient which ranged in density from $1 \cdot 088-1 \cdot 280 \mathrm{~g} / \mathrm{ml}$ with a cushion of density $1.32 \mathrm{~g} / \mathrm{ml} .{ }^{17}$ Each gradient was centrifuged at $163000 \mathrm{~g}$ for 45 minutes in a Sorvall TV-850 vertical tube rotor using a Sorvall OTD-65 ultracentrifuge. After centrifugation, 17 fractions of approximately $2 \mathrm{ml}$ were collected, and alkaline phosphatase activity was measured. The remainder of the fractions were stored at $-20^{\circ} \mathrm{C}$ before further assay. Fractionation results were averaged by computer ${ }^{18}$ and are presented in the form of frequency density histograms. Frequency is defined as that portion of total recovered activity present in an individual fraction divided by the density span covered by that fraction. Relative frequency was derived by multiplying the frequency data for enteropathogenic $E$ coli by the relative enzyme activity (mU/mg DNA) comparing enteropathogenic $E$ coli with control explants.

Brush border enzymes were assayed in the tissue, the gradient fractions and organ culture medium; alkaline phosphatase and zinc-resistant $\alpha$-glucosidase were assayed as described pre- 


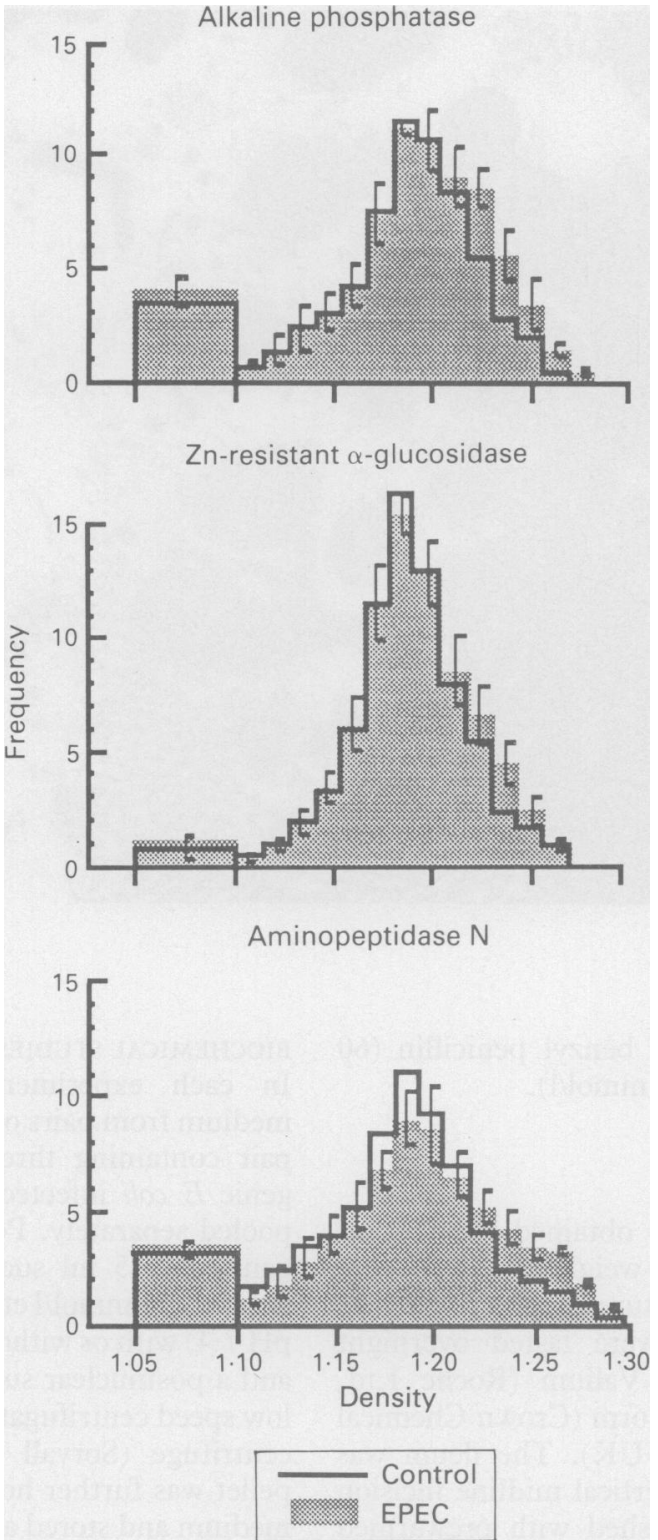

Figure 2: Reorientating sucrose density gradient centrfugation of culture medium (six) following maintenance of explants for 24 hours in the absence (control: solid line) or presence of enteropathogenic E coli (shaded, mean (SEM)). For each enzyme, areas are normalised for enzyme activity and density span $1 \cdot 05-1 \cdot 10 \mathrm{~g} / \mathrm{ml}$ represents soluble enzyme activity.

viously, ${ }^{19}$ and aminopeptidase $\mathrm{N}$ was assayed by a modification of the method of Saifu et $a l^{20}$ with $0.2 \mathrm{mmol} / \mathrm{l}$ (final concentration) L-alanine 7-amido-4-methyl coumarin (Sigma) as substrate in $0.1 \mathrm{~mol} / \mathrm{l}$ Tris $\mathrm{HCl} \mathrm{pH} 7 \cdot 2$ containing $1 \mathrm{mmol} / 1 \mathrm{Co}^{2+}$ and $0.1 \%$ Triton $\mathrm{X}-100$. Tissue DNA was assayed by the method of Labarca and Paigen ${ }^{21}$ with calf thymus DNA as standard (Sigma Type V, Poole, UK). Statistical analyses were by Student's $t$ test for paired data.

\section{Results}

\section{ULTRASTRUCTURAL STUDIES}

In each of six experiments, electron microscopic examination of control tissue maintained in organ culture for 24 hours provided no evidence of ultrastructural damage to enterocytes, and brush borders remained intact. In contrast,
Effects of enteropathogenic $\mathrm{E}$ coli on release and activities of brush border enzymes

\begin{tabular}{|c|c|c|c|}
\hline Group & $\begin{array}{l}\text { Alkaline } \\
\text { phosphatase }\end{array}$ & ${ }_{N}^{\text {Aminopeptidase }}$ & $\begin{array}{l}\text { Zinc resistant } \\
\text { ( }- \text {-glucosidase }\end{array}$ \\
\hline \multicolumn{4}{|c|}{ Release of enzymes ( $\%$ medium $/$ total $)$} \\
\hline Control & $36 \cdot 3(2 \cdot 9)$ & $39 \cdot 8(2 \cdot 0)$ & $24 \cdot 6(1 \cdot 1)$ \\
\hline $\begin{array}{l}\text { Enteropathogenic } \\
\quad E \text { coli }\end{array}$ & $\begin{array}{l}72.8(3.6) \\
{[\mathrm{p}<0.01]}\end{array}$ & $\begin{array}{l}70.8(2.9) \\
{[\mathrm{p}<0.01]}\end{array}$ & $\begin{array}{l}63.3(2.8) \\
{[\mathrm{p}<0.001]}\end{array}$ \\
\hline \multicolumn{4}{|c|}{ Specific activity ( $m U / m g$ tissue $D N A$ ) } \\
\hline Control & $267(51)$ & $794(115)$ & $142(29)$ \\
\hline $\begin{array}{l}\text { Enteropathogenic } \\
\quad E \text { coli }\end{array}$ & $\begin{array}{l}145(27) \\
\quad[p<0.05]\end{array}$ & $\begin{array}{l}560(104) \\
{[p<0.01]}\end{array}$ & $\begin{array}{l}77(16) \\
{[\mathrm{p}<0.01]}\end{array}$ \\
\hline \multicolumn{4}{|c|}{ Total activity (total mU/mg tissue DNA) } \\
\hline Control & $426(81)$ & $1310(180)$ & $190(41)$ \\
\hline $\begin{array}{l}\text { Enteropathogenic } \\
\text { E coli }\end{array}$ & $\begin{array}{l}577(12) \\
\text { [NSI }\end{array}$ & $\begin{array}{c}1920(330) \\
{[n<0.05]}\end{array}$ & $\begin{array}{c}210(39) \\
\text { [NS] }\end{array}$ \\
\hline
\end{tabular}

Data are shown as mean (SEM) (six) with statistical significance in square brackets.

NS: not significant.

Data show release, specific activities, and total activities of brush border enzymes after maintenance of ileal explants for 24 hours

either in the absence (control) or presence of enteropathogenic

$E$ coli. Release represents enzyme activity in organ culture medium as a percentage of total activity in tissue plus medium; specific activity represents enzyme activity in explant expressed as tissue $\mathrm{mU} / \mathrm{mg}$ tissue DNA; total activity represents enzyme activity in tissue plus organ culture medium expressed as total $\mathrm{mU} /$ mg tissue DNA.

explants maintained with enteropathogenic $E$ coli for eight hours showed vesiculation of microvilli where bacteria were closely adherent to the enterocyte surface (Fig 1), and by 24 hours there were large areas of brush border effacement with approximately $50 \%$ of enterocytes examined being affected. Other parts of the enterocytes appeared unaffected and there was no evidence of invasion by enteropathogenic E coli.

\section{BIOCHEMICAL STUDIES}

The brush border enzymes alkaline phosphatase, aminopeptidase $\mathrm{N}$ and zinc-resistant $\alpha$-glucosidase were released into the medium during organ culture of control rabbit ileal explants, and this process was significantly enhanced in the presence of enteropathogenic $E$ coli (Table). Increased loss was associated with decreased tissue activities of these enzymes in enteropathogenic $E$ coli infected ileal explants, while total enzyme activities in the tissue and culture medium were increased comparing enteropathogenic $E$ coli with control, although this increase only reached statistical significance for aminopeptidase $\mathrm{N}$.

Reorientating sucrose density gradient centrifugation of culture medium (Fig 2) showed that released brush border enzymes were predominantly associated with particles of peak modal density $1.19 \mathrm{~g} / \mathrm{ml}$ after incubation of explants either alone or in the presence of enteropathogenic $E$ coli. Density gradient distributions were broadly similar for all three enzymes comparing control with enteropathogenic $E$ coli, although the proportion of soluble enzyme activity (density $1 \cdot 05-1 \cdot 10 \mathrm{~g} / \mathrm{ml}$ ) was smaller for zinc resistant $\alpha$-glucosidase than for the other two enzymes.

Density gradient centrifugation of ileal explants (Fig 3) showed that maintenance in the presence of enteropathogenic $E$ coli for 24 hours resulted in a marked loss of alkaline phosphatase and aminopeptidase $\mathrm{N}$ activities from the main brush border peak of modal density $1.21 \mathrm{~g} / \mathrm{ml}$ 

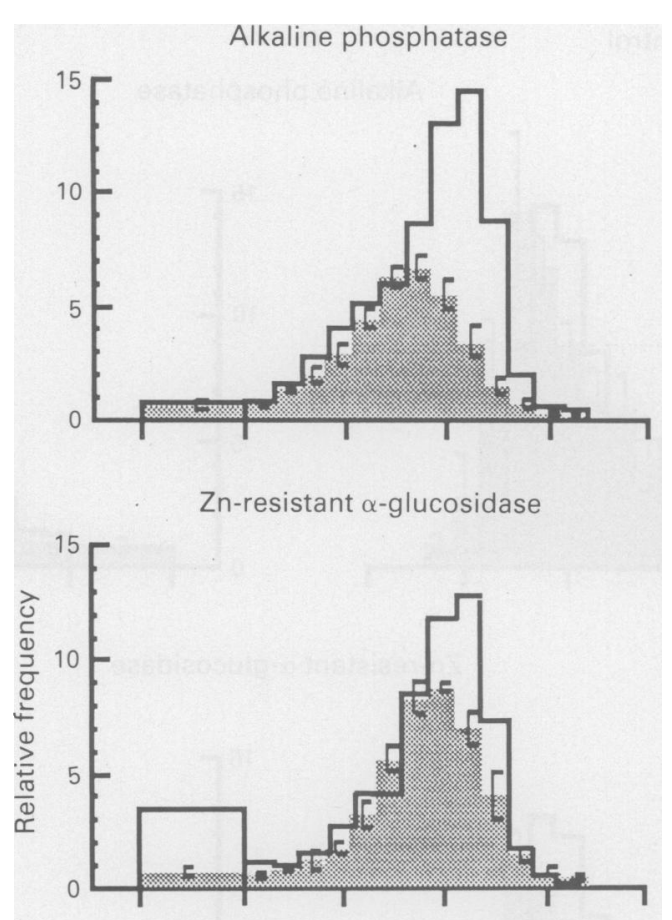

Aminopeptidase $\mathrm{N}$
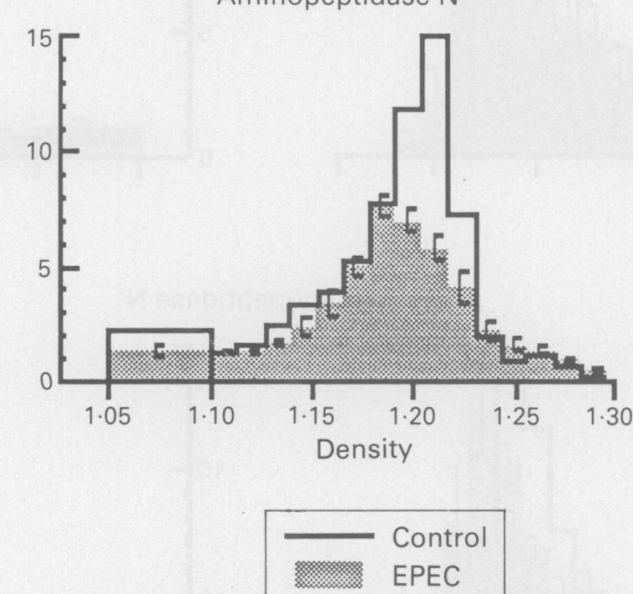

Figure 3: Reorientating sucrose density gradient centrifugation of ileal explants (six) following maintenance for 24 hours either in the absence (control: solid line) or presence of enteropathogenic $\mathrm{E}$ coli (shaded, mean (SEM)). For each enqyme, the areas comparing control and enteropathogenic $\mathrm{E}$ coli are proportional to tissue enzyme activity $(\mathrm{mU} / \mathrm{mg}$ tissue E coli are proportional to tissue enzyme activity $(\mathrm{mU} / \mathrm{mg}$ tissue
$D N A)$. The density span $1 \cdot 05-1 \cdot 10 \mathrm{~g} / \mathrm{ml}$ represents soluble enzyme activity.

present in controls, leaving a smaller and lighter peak of modal density $1.19 \mathrm{~g} / \mathrm{ml}$. In contrast, while there was a loss of brush border zinc resistant $\alpha$-glucosidase activity, there was also a marked fall in soluble enzyme activity in the enteropathogenic $E$ coli infected explants. Homogenisation of control explants in digitonin prior to density gradient centrifugation resulted in the anticipated increase in the modal density of brush borders from 1.21 to $1.23 \mathrm{~g} / \mathrm{ml}$ (Fig 4), but there was a greater increase in the modal density of brush border enzymes in enteropathogenic $E$ coli infected explants from $1 \cdot 19 \mathrm{~g} / \mathrm{ml}$ to $1.23 \mathrm{~g} / \mathrm{ml}$.

\section{Discussion}

Evidence from animal ${ }^{22} 23$ and organ culture models ${ }^{113}$ suggests that enteropathogenic $E$ coli induced ultrastructural damage is a two step process. The first stage is non-intimate attachment of enteropathogenic $E$ coli particularly to goblet cells and mucin overlying the brush border $^{12}{ }^{13}$ by a process that can involve plasmid encoded factors, ${ }^{2425}$ while the second stage involves adhesions that promote intimate attachment of bacteria to enterocytes resulting in brush border effacement with cup and pedestal formation. Diarrhoea is thought to be caused by defective absorption of osmotically active molecules, fluid and electrolytes after the loss of functional microvillar membrane proteins, but the mechanism of damage to the microvilli is unclear. Electron microscopic studies have previously shown that bacteria penetrate between and attach intimately to the base of microvilli during the second stage of the process, followed by elongation and apparent shedding of microvilli as vesicles. ${ }^{21113}$ The present study has extended these observations and provides evidence for acceleration of the normal shedding of functional microvillar membrane proteins as vesicles during the development of enteropathogenic $E$ coli mediated damage to the brush border.

Proportions of the total activities of three brush border enzymes present in the culture medium were higher for enteropathogenic $E$ coli infected than for control explants, confirming previous observations ${ }^{11}$ and indicating that enteropathogenic $E$ coli cause enhanced release of functional microvillar membrane proteins during organ culture. Reorientating sucrose density gradient centrifugation of the culture medium showed that released brush border enzymes have relatively large particulate and minor soluble components, with little difference between the normalised profiles for the two groups. The modal density of $1 \cdot 19 \mathrm{~g} / \mathrm{ml}$ was lower than for normal brush borders in control explants, and could reflect a loss of cytoskeletal components or a fall in the glycoprotein-to-lipid ratio of the membrane. These findings are compatible with an ability of enteropathogenic $E$ coli to cause vesiculation of microvilli containing intrinsic microvillar membrane proteins, and suggest that this may represent acceleration of a normal process. ${ }^{26}$ This mechanism contrasts with the loss of intrinsic microvillar membrane enzymes such as disaccharidases documented in small intestinal bacterial overgrowth, where anaerobic bacteria in particular may cause either destruction or solubilisation of these proteins from the microvillar membrane ${ }^{27-29}$; this is thought to be because of direct damage by bacteria or their secreted products, and the metabolism of intraluminal contents to potentially toxic products such as deconjugated bile acids and hydroxy fatty acids. ${ }^{30}$ In marked contrast with small intestinal bacterial overgrowth, where intraluminal bacteria can cause solubilisation of proteins from the microvillar membrane, it is now apparent that intimate contact between enteropathogenic $E$ coli and the enterocyte surface results in shedding of microvilli as vesicles still associated with intrinsic microvillar membrane proteins. The mechanism is unclear, but it has been suggested that enteropathogenic $E$ coli induced damage may be 

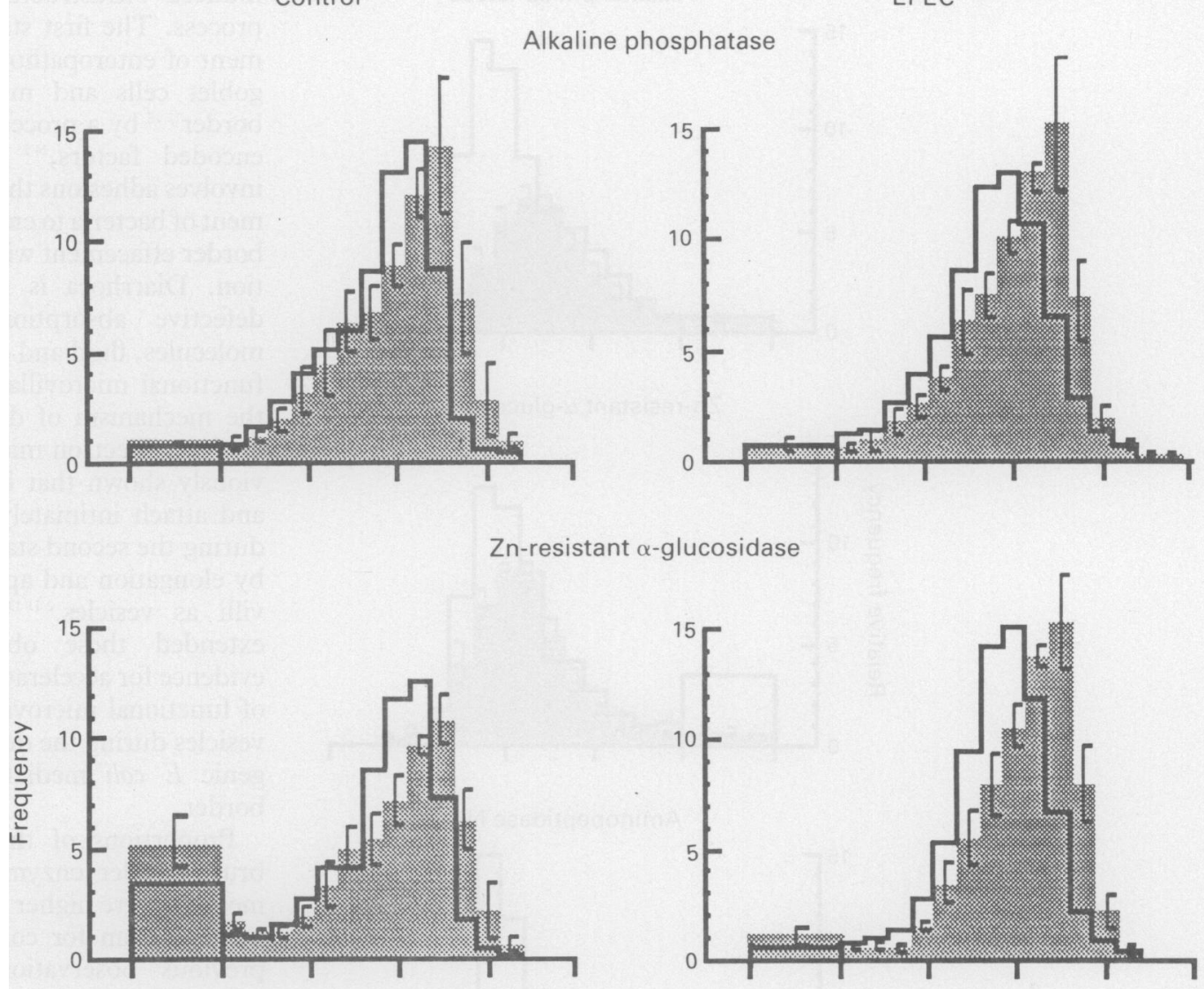

Figure 4: Reorientating sucrose density gradient centrifugation of ileal explants (six) homogenised with (shaded) or without (solid line) digitonin, after maintenance for 24 hours either in the absence (control) or presence of enteropathogenic $\mathrm{E}$ coli. For each enzyme, areas are normalised for enzyme activity and density span activity and density span
$1 \cdot 05-1 \cdot 10 \mathrm{~g} / \mathrm{ml}$ represents soluble enzyme activity.

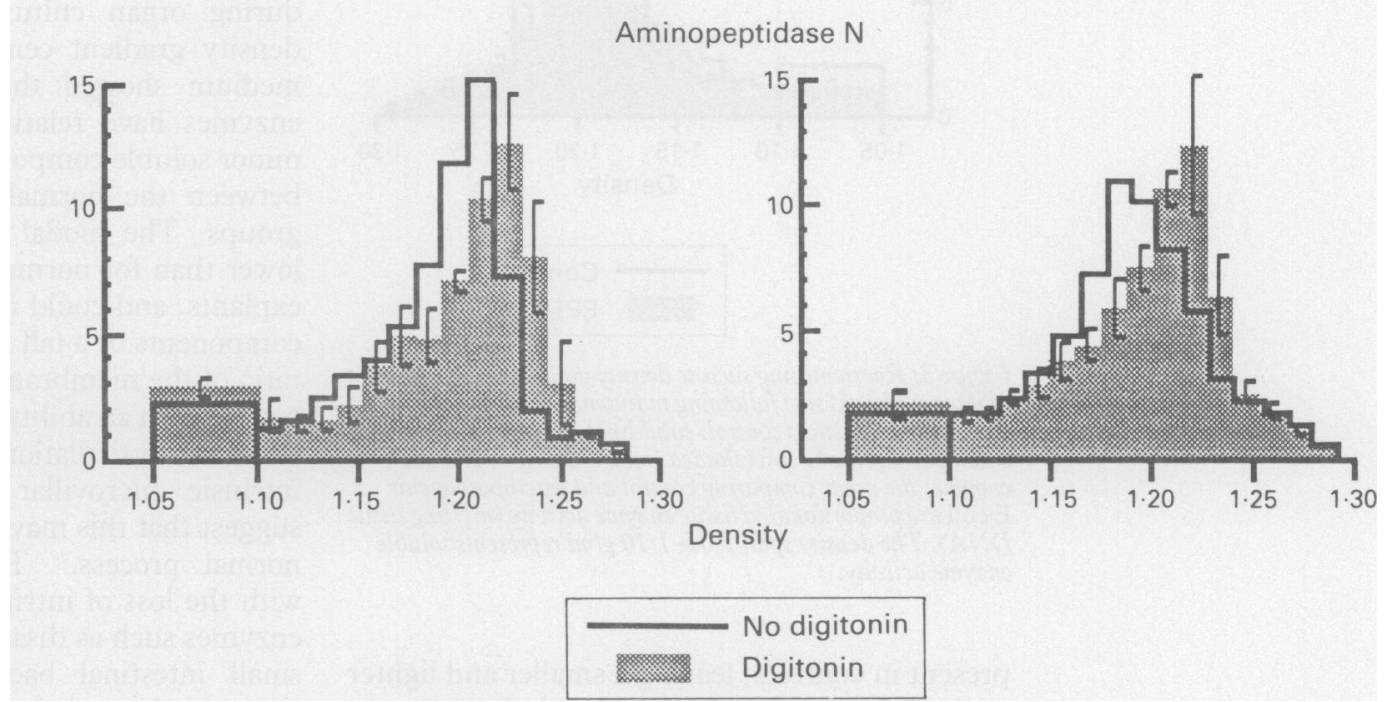

mediated by alteration in intracellular concentrations of $\mathrm{Ca}^{2+}$ resulting in activation of the calcium sensitive actin severing protein villin and degradation of the actin filaments of the microvillous cytoskeleton. ${ }^{13}$ The inability to reproduce vesiculation and effacement of microvilli by incubation of ileal explants in the presence of $\mathrm{Ca}^{2+}$ and the divalent cation ionophore A2318731 indicates that enteropathogenic $E$ coli does not act by allowing gross influx of extracellular $\mathrm{Ca}^{2+}$, but there is now some evidence that enteropathogenic $E$ coli may cause redistribution of intracellular $\mathrm{Ca}^{2+} \cdot 32$ It is difficult to reconcile such intracellular changes with the localised effects of enteropathogenic
$E$ coli, however, which affect microvilli in the close vicinity of these bacteria, while more distant microvilli of the ssme enterocyte remain intact. ${ }^{11} 12$ A lectin like property of enteropathogenic $E$ coli causing damage to microvilli by interfering with the mobility of intrinsic microvillar membrane proteins is an alternative possibility, but while certain lectins can damage microvilli it has not yet proved possible to reproduce all the ultrastructural changes associated with enteropathogenic $E$ coli. ${ }^{31}$

Specific activities of brush border enzymes were decreased in enteropathogenic $E$ coli infected explants, consistent with increased shedding of microvillar membrane proteins 
as vesicles and compatible with findings in naturally occurring infection with enteropathogenic $E$ coli. ${ }^{10}$ In a previous study, the decline in tissue activities of certain brush border enzymes in rabbit explants during culture for 24 hours was considered less than anticipated in relation to the extent of microvillar membrane damage, and it was suggested that this might indicate enhanced synthesis of these enzymes in response to increased loss from enterocytes." In which case the proportion of tissue enzyme activity in transit to the microvillar membrane might be expected to be relatively high compared with controls. In the present study, further supportive evidence for increased synthesis of brush border enzymes was provided by finding that for aminopeptidase $\mathrm{N}$ in particular there was a marked increase in total enzyme activity in the tissue and culture medium comparing enteropathogenic $E$ coli with control. In addition, analytical fractionation of ileal explants showed that enteropathogenic $E$ coli resulted in a loss of microvillar membrane enzyme activities from the main brush border peak of modal density $1.21 \mathrm{~g} / \mathrm{ml}$ present in controls, leaving a smaller and lighter peak of modal ensity $1.19 \mathrm{~g} / \mathrm{ml}$. Density increased to $1 \cdot 23 \mathrm{~g} / \mathrm{ml}$ after homogenisation in digitonin indicating that this residual peak represented cholesterol containing membranes and not endoplasmic reticulum. These findings could indicate association of these enzymes with membranes other than the microvillar membrane which could potentially be in transit to the enterocyte surface. An alternative explanation, however, is that remaining brush borders have a lower glycoprotein-to-lipid ratio or cytoskeletal content than normal, perhaps because of secreted products of enteropathogenic $E$ coli causing additional but more subtle damage at sites distant to bacterial attachment or because of the relative immaturity of the enterocytes containing residual enzyme activity.

In conclusion, we have provided physical evidence to complement electron microscopic studies showing that enteropathogenic $E$ coli induce brush border effacement by a process of vesiculation. Furthermore, our findings suggest that enteropathogenic $E$ coli induced shedding of microvillar membrane proteins as vesicles may represent acceleration of a normal process, and provide supportive evidence for compensatory stimulation of microvillar membrane protein synthesis. The possibility that such compensatory mechanisms act to repair enterocyte damage is currently being investigated.

The authors gratefully acknowledge the financial support from the Wellcome Trust.

Presented at the 92nd Annual Meeting of the American Gastroenterological Association and published in abstract form (Gastroenterology 1991; 100: A578).

1 Levine MM. Escherichia coli that cause diarrhea: enterotoxigenic, enteropathogenic, enteroinvasive, enterohemor-
rhagic and enteroadherent. $\mathcal{I}$ Infect Dis 1987; 155: 377-89.

2 Hart CA, Batt RM, Fletcher J, Embaye H, Saunders JR. Interaction of enterocytes and enteropatho

3 Ulshen MH Rollo JL Pathogenesis of Escherichia coli gastroenteritis in man - another mechanism. N Engl F Med 1980; 302: 99-101.

4 Rothbaum R, McAdams AJ, Giannella RA, Partin JC. A clinicopathologic study of enterocyte-adherent Escherichia coli. Gastroenterology 1982; 83: 441-54.
5 Levine MM, Edelman R. Enteropathogenic Escherichia coli of classic serotypes associated with infant diarrhea: epidemiology and pathogenesis. Epidemiol Rev 1984; 6: 31-51

6 Peeters JE, Charlier GJ, Halen PH. Pathogenicity of attaching effacing enteropathogenic Escherichia coli isolated from diarrheic suckling and weanling rabbits for newborn rabbits. Infect Immun 1984; 46: 690-6.

7 Tzipori S, Robins-Browne RM, Gonis G, Hayes J, Withers M, McCartney E. Enteropathogenic Escherichia coli enteritis: evaluation of the gnotobiotic pig as a model of the human infection. Gut 1985; 26: 570-8.

8 Hall GA, Reynolds DJ, Chanter N, Morgan JH, Parsons KR, Debney TG, et al. Dysentery caused by Escherichia coli (S102-9) in calves: natural and experimental disease. Vet Pathol 1987; 22: 156-63.

9 Pospichil A, Mainil JG, Baljer G, Moon HW'. Attaching and effacing bacteria in the intestines of calves and cats with diarrhea. Vet Pathol 1987; 24: 330-4.

10 Taylor CJ, Hart CA, Batt RM, McDougall C, McLean L. Ultrastructural and biochemical changes in human jejunal mucosa associated with enteropathogenic Escherichia coli 0111 infection. F Pediatr Gastroenterol Nutr 1986; 5: 70-3.

11 Batt RM, Hart CA, McLean L, Saunders JR. Organ culture of rabbit ileum as a model for the investigation of the mechanism of intestinal damage by enteropathogenic Escherichio coli. Gut 1987; 28: 1283-90.

12 Embaye H, Batt RM, Saunders JR, Getty B, Hart CA. Interaction of enteropathogenic Escherichia coli O111 with Interaction of enteropathogenic Escherichia coli O111 with rabbit intest $1079-86$.

13 Knutton SK, Lloyd DR, McNeish AS. Adhesion of enteropathogenic Escherichia coli to human intestinal enterocytes and cultured human intestinal mucosa. Infect Immun 1987; 55: 69-77.

14 Batt RM, Embaye H, Hunt J, Hart CA. Ultrastructural damage to equine intestinal epithelium induced by enteropathogenic Escherichia coli. Equine Vet f 1989; 21: 373-5.

15 Fletcher JN, Saunders JR, Batt RM, Embaye H, Getty B, Hart CA. Attaching effacement of the rabbit enterocyte brush border is encoded on a single $96 \cdot 5$-Kilobase-pair plasmid in an enteropathogenic Escherichia coli 0111 strain. plasmid in an enteropathogenic

16 Jerse AE, Yu J, Tall BD, Kaper JB. A genetic locus of enteropathogenic Escherichia coli necessary for the production of attaching and effacing lesions on tissue culture cells. Proc Natl Acad Sci USA 1990; 87: 7839-43.

17 Batt RM, McLean L, Carter MW. Sequential morphologic and biochemical studies of naturally-occurring wheatsensitive enteropathy in Irish setter dogs. Dig Dis Sci 1987; 32: 184-94

18 Leighton F, Poole B, Beaufay H, Baudhuin P, Coffey JW, Fowler S, et al. The large scale separation of peroxisomes, mitochondria and lysosomes from the liver of rats injected with Triton WR 1339. F Cell Biol 1968; 37: 482-513.

19 Batt RM, Peters TJ. Subcellular fractionation studies on peroral jejunal biopsies from the dog. Res Vet Sci 1978; 25: peroral jeju.

20 Saifu K, Sekine T, Namihisa T, Takahashi T, Kanaoka Y. A novel fluorimetric ultramicro determination of serum leucine aminopeptidase using a coumarin derivative. Clin Chim Acta 1978; 84: 85-91

21 Labarca C, Paigen KA. A simple rapid and sensitive DNA assay procedure. Anal Biochem 1980; 102: 344-52.

22 Cantey JR, Lushbaugh WB, Inman LR. Attachment of bacteria to intestinal epithelial cells in diarrhea caused by Escherichia coli strain RDEC-1 in the rabbit: stages and role of capsule. F Infect Dis 1981; 143: 219-30.

23 Boedeker EC. Mechanisms of adherence of Escherichia coli to enterocytes: their possible role in intractable infant diarrhea. In: Lebenthal E, ed. Chronic diarrhea in children. New York: In: Lebenthal E, ed. Chro
Raven, 1984: 329-45.

24 Sherman PM, Boedeker EC. Pilus mediated interactions of the Eschericia coli strain RDEC-1 with mucosal glycoproteins in the small intestine of rabbits. Gastroenterology 1987; 93: $734-43$.

25 Wolf MK, Andrews GP, Fritz DL, Sjogren RW Jnr, Boedeker EC. Characterization of the plasmid from Escherichia col RDEC-1 that mediates expression of adhesion AF/R1 and evidence that $A F / R 1$ pili promote but are not essential for enteropathogenic disease. Infect Immun 1988; 56: 1846-57.

26 Scott J, Peters TJ. Protection of epithelial function in human jejunum cultured with hydrocortisone. Am $\mathcal{F}$ Physiol 1983 ; 244: G532-40.

27 Riepe SP, Goldstein J, Alpers DH. Effect of secreted Bacteroides proteases on hum an intestinal brush border Bacteroides proteases on hur an intestin
hydrolases. $\mathcal{f}$ Clin Invest $1980 ; 66: 314-22$.

28 Jonas A, Flanagan PR, Forstner GG. Pathogenesis of mucosal injury in the blind loop syndrome. Brush border enzyme
inges activity and glycoprotein degradation. $\mathcal{F}$ Clin Invest 1977 60: $1321-30$

29 Jonas A, Krishnan C, Forstner G. Pathogenesis of mucosal injury in the blind loop syndrome. Release of disaccharidases from brush border membranes by extracts of bacteria obtained from intestinal blind loops in rats. Gastroenterologv 1978; 75: 791-5.

30 King CE, Toskes PP. Small intestine bacterial overgrowth Gastroenterology 1979; 76: 1035-55.

31 Hart CA, Batt RM, Saunders JR, Getty B. Lectin-induced damage to the enterocyte brush border: an electron microscopic study in rabbits. Scand $\mathcal{F}$ Gastroenterol 1988; 23: 1153-9.

32 Baldwin TJ, Ward W, Aitken A, Knutton S, Williams PH Elevation of intracellular free calcium levels in $\mathrm{HEp}-2$ cells infected with enteropathogenic Escherichia coli. Infect Immun 1991; 59: 1599-604. 